DOI https://doi.org/10.36059/978-966-397-215-2/111-132

\title{
FORMATION OF MEDIACULTURE AS A DIRECTION OF SCIENTIFIC RESEARCH
}

Uvarova T. I.

\section{INTRODUCTION}

Culture is a continuous process of transformation of information paradigms. A new civilizational turn of the beginning of the XXI century caused by the information technology revolution. Changes have occurred in all areas of culture, including institutional changes the media culture (media culture) is undergoing. The relevance of cultural studies of media culture lies in the scientific understanding of the essence, potential and prospects of the impact of new media on all spheres of life.

\section{The concept of "mediaculture"}

Despite the fact that a new type of culture, which began to take shape with scientific and technological discoveries and related technological changes as early as the twentieth century, mediaculture as a special type of culture of the information society, weathered in an independent direction only in the early twenty-first century. It became the subject of scientific discussions and research by cultural scientists, philosophers and sociologists, etc. In their understanding, media culture becomes a manifestation of culture itself and is interpreted as universal access to culture for people through mass media products.

A significant role in the study of mediaculture functioning belongs to scientists T. Adorno, G. Arneheim, A. Bazen, R. Bart, V. Benjamin, J. Bodriar, J. Derrida, J. Deleuze, S. Zhijek, M. Castells, M. McLuena, H. Marcuse, N. Luman, H. Ortega-and-Gasset, M. Foucault. Foreign scientists (D. Bell, W. Boltz, P. Bourdier, A. Gouldner, Y. Kristeva, C. Levi-Strauss, C. Pierce, G. Pollock, F. de Sossiur, E. Toffler, D. Rushkoff, and R. Harris), Russian scientists (V. Kristeva, C. LeviStrauss, and M. Foucault) also devoted their research to the specifics of media and their impact on society. Bibler, V. Borev, A. Elyakov, I. Erofeeva, M. Zhizhina, A. Kalmykov, N. Kirillova, L. Kohanovo, K. Razlogov, A. Chernykh) and Ukrainian researchers (N. Korableva, 
N. Lupak, D. Sizonov, A. Sobol, V. Sudakova, G. Chmil, R. Shulga, etc.). In spite of the fact that a wide range of problems related to the content, functions and specificity of media have become the object of theoretical attention of a number of scientists, there are still many "white spots" in the research space of this phenomenon, which actualize the need for further scientific research, including the definition of the concept of "mediaculture" and understanding of the peculiarities of "new media" functioning in modern culture.

Marshall McLuen, a Canadian sociologist and publicist, was one of the first to use and introduce the term "media" to a wide range of scientific uses, investigating the daily life of a person in the information society. The term itself comes from the Latin medium - something middle, something that occupies an intermediate position, a middle, a center. In mythological tradition, the medium is a priest, shaman, sorcerer, fortune teller who combined semantic opposition: earth and sky, spirit and body, asserting their existence. In different languages the word medium means "means", "mediator", "medium" and others. Despite its origin, "media" has never been interpreted as a simple "intermediary" in the transmission of information. Especially in modern times, when media does not appear as a participant in a communication act, but can influence all its elements. Most often today, the term "media" refers to the totality of channels for transmitting and storing information of various types.

Mediaculture should be viewed from the perspective of studying two main terms: media and culture. The definition of media is interpreted as a means of communication and transmission of information of various types - from the oldest (gestures, pictures, etc.) to modern ones, using integrated hybrid digital telecommunication networks (Internet, mobile telephony, etc) ${ }^{1}$. Culture is the basis of this phenomenon in the context of its functioning as a sign system, as a "code" through which information about a person in the surrounding world is transmitted.

According to the scientist V. Vozchikov, media culture is a "coded" reality, a symbolic existence of real experience in the form of media messages intended for perception ${ }^{2}$. Media culture is a complex means of human exploration of the surrounding world.

1 Землянова Л. М. Коммуникативистика и средства информации. Англорусский толковый словарь концепций и терминов. Москва, 2004. 416 с., С. 197.

${ }^{2}$ Возчиков В. А. Философия образования и медиакультура информационного общества: дис. ... д-ра филос.: 09.00.11 / Вячеслав Анатольевич Возчиков. - СанктПетербург, 2007. - 413 с, С. 359-360. 
Mediaculture is also understood as "an independent form of culture, generating new languages and meanings" ${ }^{3}$. Mediaculture is seen as "part of the general sphere of human culture. It, like culture as a whole, is designed to regulate human behavior, to organize human activity, knowledge and creativity, to form a field of preservation of traditions and emergence of innovations" ${ }^{4}$. This anti-entropic essence of culture, its ability to develop structures, improve the level of social organization and counteract chaos is reflected in the history of the word culture.

According to S. Alferova, media culture is "a multifunctional type of culture of the modern era. Mediaculture makes it possible to accumulate and multiply public information at a rapid pace and in geometric progression" 5 . The researcher considers modern media culture to be "the guarantor of the nation's social memory, an effective catalyst for the exchange of cultural information and a component of communication between the authorities and society, different countries, nations, social groups, individuals, etc". <..> Mediaculture provides ample opportunities for people to communicate in time and space, overcoming centuries and distances, but the paradox of the current situation is the numerous contacts through the media and, at the same time, the lack of communication, acquires signs as a socio-cultural and psychological problem. Mediaculture is responsible for the process of socialization of the individual, acquisition of social experience, knowledge, norms, ideals inherent in society or a social group. These include customs and traditions, etiquette, laws, that is, everything that together forms complex complexes such as law, morality and ideology. In addition, media culture has become the backbone of today's entertainment industry, which offers

${ }^{3}$ Верховская С. Б. Медиакультура как фактор трансформации сознания // Вестник угроведения № 2 (5), 2011. Философия, социология, політологія. C. 93-99.

${ }^{4}$ Етимологічний словник української мови: В 7 т. - Т. 6: У-Я / Ред. кол.: О. С. Мельничук (гол. ред.), В. Т. Коломієць, Т. Б. Лукінова, Г. П. Півторак, В. Г. Скляренко, О. Б. Ткаченко; Укладачі: Г. П. Півторак, О. Д. Пономарів, I. А. Стоянов, О. Б. Ткаченко, А. М. Шамота. НАН України. Ін-т мовознавства ім. О. О. Потебні. - К.: Наукова думка, 2012. - 568 с., С. 138.

${ }^{5}$ Алферова 3. И., Алферов А. Н., Національне та європейське в сучасній українській медіаосвіті // Культура України. Сер. Мистецтвознавство: зб. наук. пр. / Харків. держ. акад. культури; за заг. ред. В. М. Шейка. - Харків: ХДАК, 2016. - Вип. 53. - 372 с., С. 174-185. 
a wide range of special relaxation means - from films of different genres to interactive computer games ${ }^{6}$.

D. Kellner defines media culture as: "Mediaculture is the culture of images, sounds and images transmitted through certain technical means: radio, film, television, music, printed media such as magazines, newspapers, comics, etc" ${ }^{7}$.

Researchers F. Jamison, J. Bodriard, P. Virillo considered mediaculture as a field of culture, which is associated with the broadcast of dynamic images, which are widely used by modern technical means of recording and transmission of image and sound (film, television, video, multimedia systems).

The notion of mediaculture is seen as part of mass communication. As well as socio-cultural phenomena related to media (world of books, world of television, world of newspapers and magazines, world of radio, world of Internet resources). From a personal point of view - as a human culture, and more narrowly - as a mediaculture of a person - his creative expression and possession of communication tools that ensure full involvement of a person in society.

Mediaculture united peoples, social groups and states. And, to a certain extent, thanks to it, the process of cultural self-consciousness, the definition of one's own unique identity, takes place. So, mediaculture is a social mediator, which establishes links between the structures of society ${ }^{8}$.

Mediaculture in research also appears as a management tool. "It is natural that media are called the "fourth power", given its multifaceted and far-reaching power over people's feelings and consciousness"" .

Summarizing the aforesaid, it can be stated that there is no unambiguous opinion on the definition of "media culture" at present. The majority of authors of scientific works, publications on the issues of

${ }^{6}$ Алферова 3. И., Алферов А. Н., Національне та європейське в сучасній українській медіаосвіті // Культура України. Сер. Мистецтвознавство: зб. наук. пр. / Харків. держ. акад. культури; за заг. ред. В. М. Шейка. - Харків: ХДАК, 2016. - Вип. 53. - 372 с., С. 174-185.

${ }^{7}$ Kellner D. Media Culture: Cultural studies, identity and politics between the modern and postmodern / D. Kellner. - London ; New York, 2000. - 357 p., P. 1-3.

${ }^{8}$ Алферова 3. И., Алферов А. Н., Національне та європейське в сучасній українській медіаосвіті // Культура України. Сер. Мистецтвознавство: зб. наук. пр. / Харків. держ. акад. культури; за заг. ред. В. М. Шейка. - Харків: ХДАК, 2016. - Вип. 53. - 372 с., С .174-185.

${ }^{9}$ Ibid. 
formation and development of information space culture tend to the position, according to which the basis of media culture should be the system (totality) of material and intellectual values in the field of media, the level of development of a personality capable of perceiving, analyzing, evaluating the media text, getting involved in media creativity, learning new knowledge through media means. However, most researchers believe that the most complete definition is presented in the works of N. B. Kirillova. She defines media culture as "a set of information and communication means, material and intellectual values developed by mankind in the course of cultural and historical development that contribute to the formation of public consciousness and socialization of the individual" ${ }^{10}$.

From this point of view, media culture includes a culture of provision and transmission of information, as well as a culture of perception of it. In addition, media culture can, to a certain extent, be an indicator of the level of development of a person capable of engaging in media creativity, learning new knowledge about media, perceiving, analyzing and evaluating media text.

\section{The phenomenon of mediaculture in research approaches}

Modern science is characterized by a growing interest in the theoretical justification and practical formation of mediaculture. A significant number of strategies of media phenomenon research have been defined in the theoretical plane.

The communicative approach allows exploring media culture as a form of communication relations. One of the first to apply this approach was H. McLuen. Proceeding from the fact that communication is one of the key notions of media theory, in H. McLuen's works media culture appears as a set of dissimilar subjects and phenomena of the modern level of cultural development. In essence, he created a new cultural typology, which considered the history of culture through the prism of evolution of types of communication - from tactile and oral through written and printed to audiovisual. M. McLuen explained the notion of communication media in a rather broad, comprehensive way: not only radio, cinema, telephone, but also housing, road, wheel, mirror, clothes, road, etc. This understanding of culture radically shifts the emphasis

${ }^{10}$ Кириллова Н. Б. Что такое медиакультура // ТелеЦЕНТР. 2005. № 4 (12). C.19-21. 
in the study of cultural development, all interactions in it arise before the researcher Culture as a form of communication relations. "All these "technologies", or "mediators", the introduction of which will significantly change the communication of man with the world around him (both natural and social) and reorganizes his way of thinking and way of life," - writes G. McLuen in his paper "Media Understanding: the external expansion of man"11. These "funds" are considered by D. McLuen as "External Extensions" of a person, as a direct technical extension of a person, his body, organs, his abilities. In his book, he wrote that the effect of this expansion occurs much earlier than mankind has time to realize it and understand what happened. "We are moving into the future as the driver of a car who looks only in the rearview mirror when driving," says the author, emphasizing that the impact of the latest technology we begin to realize only when they become obsolete ${ }^{12}$.

Analyzing the dynamics of culture on the basis of a communication approach, YM Lotman wrote that "no culture can do without a single language. The minimum system is formed by a set of two parallel languages - for example, verbal and visual"13. The distribution of information also depends on the choice of language. From the point of view of the choice of the language of communication, media culture is a complex phenomenon, because when broadcasting a message through media channels, several languages are always used simultaneously, which creates different semantic layers, complicates understanding and generates ambiguity of interpretations. "Media speech, like any other language, is technology," wrote G. McLuen.

The civilization approach allows exploring media cultures through the correlation of the notion of "civilization". The development of communication media, in this vein, is considered as a powerful factor in accelerating historical development. Functioning of mass media in each cultural-historical epoch forms the corresponding type of media culture, which creates the image of this epoch. Modern media, which are constantly transformed under the influence of scientific and technological progress, influence the sphere of production, management and communication, and generally accelerate all civilizational processes.

${ }^{11}$ Маклюэн Г. М. Понимание Медиа: Внешние расширения человека / пер. с англ. В. Николаева; закл. ст. М. Вавилова. М.-Жуковский: «КАНОН-прессЦ.», «Кучково поле», 2003. 464 с.

12 Ibid.

${ }^{13}$ Верховская С. Б. Медиакультура как фактор трансформации сознания. С. 98. 
American mediologist Douglas Rushkoff introduces the term "Infosphere", which means numerous means of transmitting and modifying information. The Infosphere, or media space, according to D. Rushkoff, is "a new territory open to human interaction, economic expansion, and especially to social and political machinations" ${ }^{14}$. It is the infosphere that it interprets as a continuation of human species evolution, as an expansion of the planetary ecosystem, as a nutrient environment in which culture develops. That is, according to D. Rushkoff, the only environment in which civilization is able to develop is the media environment. And the power, which a man can be endowed with, is already reduced not to the number of human property, but to the media hour, which he can get. D. Rashkoff notes that the continuously growing media sphere has become quite real. Information that mankind will not be able to manage over time, in his opinion, can lead to significant social changes. Thus, the civilizational approach allows to consider media culture as a subsystem of society. It emerges as a civilizational factor that leads to changes in society, culture, spiritual life of the society.

Anthropological view on the study of media culture focuses on innovative shifts that change the basic for the civilizational development of mankind anthropological characteristics. The man lives in the world filled with meanings and values of creative activity of the community which has constructed the social reality. Norms of behavior, which would be generally accepted, are produced in the process of communication, including through mass media, which smooth out the traditional differences in the worldview of people, mixing private life realities in a common stream. The media are changing the way people perceive the world, think and behave. It informs them about the state of the world, fills their leisure time, and affects the type of culture in society at a certain historical period.

Proponents of E. Durkheim's structural-functional approach concentrate on the problem of public perception of media content, analyze methods of forming collective ideas, in particular, investigating the problem of manipulation of public opinion and considering the possibilities of media integrative function in society. The original concepts of media research belong to M. McLuen ("ecological" concept of "world

${ }^{14}$ Рашкофф Д. Медиавирус. Как поп- культура тайно воздействует на ваше сознание [Электронный ресурс] // Библиотека Гумер - гуманитарные науки. URL: http://www.gumer.info/bibliotek_Buks/ Gurn/Rashk. 
village") ${ }^{15}$, E. Toffler and M. Castells (Post-industrial Information Society concept) ${ }^{16}$, G. Deboru (society of the play) ${ }^{17}$, which are an attempt to create models that describe the regularities of functioning and make it possible to predict the future development of media.

The followers of M. Weber's antipositivist paradigm analyze and build a system of meaning of the rational component in cultural activities, focusing on the issues of media organization and their inclusion in the social organism.

Important for studying the influence of media on the regulation of human behavior is the socio-psychological approach, in which the Freudo-Behavioral Concept of Communication of G. Lassuella is noted ${ }^{18}$ and W. Lippman's concept of public opinion ${ }^{19}$.

The studies of neo-Marxist direction, which pay attention to the symbolic meanings of media texts, considering them through the prism of the relationship between the base and superstructure, in which the media are presented as an element of the superstructure, are quite widely presented. According to the neo-Marxist tradition of the Frankfurt School (M. Horkheimer, T. Adorno) ${ }^{20}$. works by the Birmingham "Centre for Contemporary Cultural Studies" ${ }^{21}$. There is increased attention to the impact of media on cultural formation and development. Media in neo-Marxist tradition are considered not only as a "mouthpiece" of power for propaganda of the prevailing ideology, but also as a part and even a characteristic of culture. In this context, we can

\footnotetext{
${ }^{15}$ McLuhan M., Fiore Q. War and Peace in the Global Village. - N.Y.: Bantam, 1968.

${ }^{16}$ Кастельс М. Информационная эпоха: экономика, общество и культура / Мануэль Кастельс; [пер. с англ. под науч. ред. О. И. Шкаратана]. - М.: ГУ ВШЭ, 2000. - 608 с.

17 Дебор Г. Общество спектакля / Ги Дебор; [пер. с фр. С. Офертаса и М. Якубович]. - М.: Логос, 1999. - 224 с.

18 Лассуєлл Г. Д. Психопатология и політика [Ел. рес.] / Г. Д. Лассуєлл. Режим доступу: http://sbiblio.com/biblio/archive/lasuel_psi.

19 Липпман У. Общественное мнение / Уолтер Липпман; пер. с англ. Т. В. Барчунова, под ред. К. А. Левинсон, К. В. Петренко. - М.: Институт Фонда «Общественное мнение», 2004. - 384 с.

20 Хоркхаймер М., Адорно Т. В. Диалектика просвещения. Филофоские фрагмен- ты / Макс Хоркхаймер, Теодор В. Адорно; [пер. с нем. М. Кузнецова]. М.-СПб.: Медиум, Ювента, 1997. - 312 с.

${ }^{21}$ Черемушкина Е. Ф. Основоположник британських «культурных исследований» Ричард Хогарт. [Електронний ресурс] / Е. Ф. Черемушкина. Режим доступу: http://study-english.info.
} 
consider the concept of the famous French sociologist Pierre Bourdier ${ }^{22}$, who, in his theory of the social field, considers the social space in which the human being functions.

The scientific views presented above demonstrate a variety of interpretations and vectors of research of such a complex and multifaceted phenomenon as mediaculture.

\section{Mediaculture: culturological interpretations of basic concepts}

The notion of mediacultures is associated with a number of notions "mass media", "media space", "new media", "social media", etc. These terms can hardly be called equivalent to the notion of "media culture", as they reflect only one aspect of the existence of this complex phenomenon. Therefore, in our opinion, we should resort to a more precise interpretation of these concepts.

In research media cultures use the term "media space". As a separate scientific phenomenon "media space," Western scientists began to think about it only in the mid-twentieth century. In English-language literature, the concept of "media space" has been used since the $1980 \mathrm{~s}$. In studies by M. McLuen and R. Stults and S. Harrison. In Ukrainian scientific thought, the term "media space" was introduced into scientific circulation in the $90 \mathrm{~s}$ of the 20 th century, primarily due to the fact that this concept is inextricably linked with the terms "media" and "mass media". In spite of the fact that nowadays the term "media space" is widely used in scientific literature, today there is no unambiguous interpretation of the term, which is connected with several factors. "Firstly, next to the concepts of media space "other terms are used as synonymous or close in meaning, in particular "media sphere", "information space", "informationcommunication space", "mass-media space", etc. Secondly, the absence of a generally accepted definition of the notion of "media space" is due to the fact that representatives of various sciences addressed the scientific understanding of the essence of this phenomenon, who considered the "media space" as "human cultural heritage, artificially created environment"'"23, as "a set of organically ordered institutions responsible for the development, collection, processing, design, transmission of

22 Бурдье П. Социология политики / Пьер Бурдье // Социология политики; [пер. с фр. Н.А. Шматко]. - М.: Socio-Logos, 1993. - 336 с.

23 Нові медіа в сучасному суспільстві: культурологічний вимір: монографія / В. М. Судакова, М. Ю. Наумова та ін. - К.: Інститут культурології НАМ України, 2017. - 352 с., С. 24. 
socially significant information through various levels of information technology and information-material complexes that affect a particular social environment, whose representatives are able to perceive and understand information messages ${ }^{24}$.

Consequently, according to the Canadian scientist M. McLuen, "media space is a way for people to expand. In other words, the expansion of human capabilities and, at the same time, the narrowing of space itself, accessibility to viewing and participation in events in different parts of the world" 25 . The scientist points out in his works that the development of technologies creates prerequisites for the formation of a global media space and "the transformation of communication into a productive force, which leads to the need to go beyond the European socio-cultural system and subordinate it to the new global management trends associated with overcoming national and state borders and cultural and civilization processes.

Reflection on the notion of "media space" is also observed in the research of Jean Beaudriard, who in his work "Simulacra and Simulations", paying attention to the impact on the personality of media, concluded that they form a hyper-reality that does not correspond to reality-there is a displacement of reality and its replacement by simulacra - certain iconic symbols that are not related to the basic reality, but form a parallel reality. Mass media, under such conditions, is not just a set of technical means to disseminate the content of information, it is a system of imposing models, so the media strengthen the demonstrative nature of any political action ${ }^{26}$.

The culturological approach considers the media space as part of the symbolic space of signs, which leads to its definition as a hypertext structure. In particular, Arjun Appadurai and Malcolm Waters speak about media space as a special symbolic sphere of culture. At the same time, Appadurai singles out the media space into one of five cultural and symbolic spaces-landscapes-in the global cultural flow. Appadurai's

${ }^{24}$ Нові медіа в сучасному суспільстві: культурологічний вимір: монографія / В. М. Судакова, М. Ю. Наумова та ін. - К.: Інститут культурології НАМ України, 2017. - 352 с., С. 19.

${ }^{25}$ Маклюэн М. Понимание медиа: внешние расширения человека [Электронный ресурс] / Маршалл Маклюэн; [пер. с англ. В. Николаева]. - М.: Канон-Пресс, 2003. - 458 с., С. 301.

${ }^{26}$ Бодріяр Ж. Симулякри і симуляція / Жан Бордіяр. - К.: «Основи», 2004. $-230 \mathrm{c}$. 
media space gets the characteristics of a fluid, unstable space, which is a "building block" of those "imaginary worlds" in which people interact with each other ${ }^{27}$. M. Waters subsequently modifies the classification of flow spaces by A. Appadurai and combines it with the concept of J. Bodrijar's simulacres. Thus, the media space ("sacroprosdtransism" in M. Waters' theory) is one of the "dimensions" of the culture formed by the flow of simulacrum information ${ }^{28}$.

Another angle on "media space" in culurology is its consideration in the aspect of interaction of national cultures. The "media space" can be seen as a "channel of transmission of spiritual values at the level of the world community. $<\ldots>$ All substantive texts that are included in the flows of media space have certain meanings and ideas in mind. <...> Media space is a chaotic system of spiritual and value information, which offers, in accordance with different interests and needs of users, the necessary spiritual and cognitive environment, free from dictate and comfortable for social choice of individuals" - says S. Kulibaba. In his opinion, "the key task of individuals, social groups and the state as a whole is to find drivers in the media space for the transmission of integrating terminal spiritual values" ${ }^{29}$.

Such an understanding of the "media space" is presented in the works of L. Zubanova, who understands the media space as "the value space of modern mass media - the "arena" of value interaction of communication participants, the "tribune" of broadcasting significant guidelines for social development. <...> We are dealing with a special organization of space associated with symbolic forms - a wide range of texts and images that are created and recognized by subjects as semantic constructions that form a cultural order through models of explaining reality" ${ }^{\prime \prime 2}$.

27 Appadurai A. Disjuncture and Difference in the Global Cultural Economy [Electronic resource] / Arjun Appadurai // Theory Culture Society. - 1990. Vol. 7. - P. 295-310. - Access mode www.unc.edu/ jbecks/comps/pdf/appadurai_ disjuncture.pdf (Accessed 20 Febrary 2015) 12. 1, p. 296-299.

${ }^{28}$ Waters M. Globalization / Malcolm Waters. - L.: Routledge. - 1996. - 185 p.

29 Кулибаба С. И. Медиапространство и трансляция духовных ценностей [Электронный ресурс] / Сергей Иванович Кулибаба // Материалы Международ. науч. конф «Медиакультура новой России: методология, технологии, практики» / [под ред. Н. Б. Кирилловой и др.]. - 2007. - Т.2 - С. 125-134. Режим доступа: http://vk.com/doc-54830594_213541276.

${ }^{30}$.Зубанова Л. Б. Современное медиапространство: подходы к пониманию и принципы интерпретации [Электронный ресурс] / Л. Б. Зубанова // Вестник Челябинской государственной академии культуры и искусств. - 2008. - № 2 (14). C. 6-17. Режим доступу: http://elibrary.ru/contents.asp?issueid=521114. 
Culturologists also consider the media space in the context of the new challenges of our time, namely the globalization of the media space. According to N. Kirillova, these are "preservation of national identity in the communicative space", "dialogue of cultures" and "cultural pluralism", "interpretation of cultural heritage", "risks and alternatives of the future culture", "possibility of existence of a single world culture" ${ }^{31}$.

The sociological approach sees the "media space" as a component of a social space with the ability to design social constructions based on specific, inherent means (print and electronic media). In sociology, the idea of media space has been formed through the prism of the influence of mass media as a separate social institution on social processes, the formation of public opinion, political image, etc. Media space is seen as an open system of relations between media producers and consumers, which always takes the form of the social and political structures within which it functions" ${ }^{32}$. Since the media space is a social system, all its structural elements: TV space, radio space, press space, Internet, etc., are interconnected and subject to the general laws of the whole development. Therefore, this approach sees the media space as a special sphere of relations between people and communities (individuals and groups) in the process of collecting, producing, disseminating and consuming information.

Media space, as part of the physical environment, is also viewed through a technological approach, where it is perceived as a collection of databases and databases, technologies for their use, information and telecommunication networks and systems.

From the perspective of journalism theory, synonymous to the notion of media space is the notion of "media environment", which is understood as a set of technical and software media (technical means) that are used to create, record, copy, replicate, store, distribute, perceive and exchange information between the author of the media text and those who perceive it. That is, the media space is a collection of sources from which people receive information and the semantic field that these

${ }^{31}$ Кириллова Н. Б. Многообразие культур в глобальном медиапространстве [Электронный ресурс] / Н. Б. Кириллова // Известия Уральского государственного университета. Сер. 2, Гуманитарные науки. - 2006. - № 47, Вып. 12. - С. 58-68. - Режим доступа : http:// hdl.handle.net/10995/23304

32 Пискун Т. В. Медиапространство как особая социальная структура: к методологии вопроса [Электронный ресурс] / Т. В. Пискун // Режим доступа: www.readera.org/article/medyeaprostranstvo-kak-osobaja-sotsyealnaja-0-10118474.html. 
sources form ${ }^{33}$. In the modern world of intensive information exchanges the media space has turned into an important component of modern society functioning, because it influences the modern culture through all totality of channels of formation, transfer and storage of information.

Obviously, the notion of "media space", from the point of view of its multidimensionality and synthetic character, gravitates towards its interdisciplinary definition. At the same time, it should be noted that despite the ramified web of interpretations, which entangles the definition of the notion of media space, the majority of authors point to the necessity of its integral understanding in connection with the notion of "mass media", since media are an important subject of media space formation.

The concept of "mass media" comes from the lat. Massa - pile and media - medium, medium, medium, mediator. This term has appeared relatively recently. In the domestic culturology, the concept of "mass media" and means of mass communication was more popular, while in the foreign scientific space the concept of "mass media" was used. The term "mass media" (short for "mass communication media") in scientific thought is understood as a set of methods and means by which centralized suppliers transmit, distribute and distribute information and other forms of symbolic communication to a large, diverse and geographically dispersed audience. The term "mass media" so far also applies to organizations that control these technologies, such as television channels or publishing houses.

"Mass media" - is a means of mass communication in society and reaches a fairly wide audience. Characteristic features are appeal to a mass audience, accessibility to a mass audience, and the industrial nature of content production and distribution. The stages of media development are closely linked to changes in society. Thus, the emergence of the first newspapers in the 18th century is most directly connected with the entry into the political arena of a new class - the bourgeoisie, for which they have become a means of realizing economic, political and cultural goals (it was then that the metaphor "fourth power," which recorded their great importance in society, authorship of which is attributed to both English novelist H. Fielding and political philosopher E. Burke). Subsequently, the mass media

33 Литвинович М. Как интернет меняет медиапространство. Интеллектуальная Россия. [Электронный ресурс] / Марина Литвинович // Интерлос. - Режим доступа: www.intelros.ru/intelros/reiting/reyting_09/ material_sofiy/8763-kak-internetmenyaetmediaprostranstvo.html. 
became almost the main instrument of economic and political interactions and conflicts, a necessary prerequisite for the establishment of liberal economy and constitutional democracy, as well as bureaucratic economies, authoritarian and totalitarian political regimes. The development of mass media was in step with progress in social and cultural organisation. "Urbanization, the rise of life standards and free time, the formation of modern bureaucracy and other global socio-cultural processes would have been impossible in the absence of mass media, which is not only one of the symbols of the modern world, but also a very active catalyst for all social changes ${ }^{34}$.

Behind the concept of "mass media" there is a complex and diverse set of structures and activities, each of which has its own way of communication and audience: television, radio, journalism, photojournalism, press, music industry, cinema, sound and video recording, news agencies, publishing business, Internet.

The term "new media" is associated with the notion of "mass media". The emergence of the concept of "new media", with an emphasis on the characteristic of "new media", indicates the beginning of a different stage than the previous one. What has become the driving force and the factor of new shifts in culture, including media culture as one of its important components? The notion of "new media" is connected with the history of mass media development and grand social transformations. First of all, due to the change of the traditional model of information dissemination at the beginning of the XXI century. With the advent of the interactive Internet, the information flow began to be regulated not only by producers, but also directly by consumers of information.

For the first time, the term "new media" appeared at the end of the last century. The starting point of the new media era is considered to be April 19, 1995, when the terrorist attack in the city of Oklahoma American journalists began to actively post all the facts on the Internet. In fact, within one day the global network turned from a simple means of storing information into a fairly strong competitor to television. Thus, the notion of "new media" began to be used to separate

34 Наумова М. Ю. Нові медіа та традиційні 3МІ: моделі співіснування / М. Ю. Наумова // Актуальні проблеми соціології, психології, педагогіки. 2011. - Вип. 13. - С. 86-92. - Режим доступу: http://nbuv.gov.ua/UJRN/apspp_ 2011_13_16. 
traditional media (television, radio and press) from the Internet ${ }^{35}$. Until then, the basis for media - periodicals, radio and television - was analogue and printed media. "However, with the rapid development of digital, network, computer, information, game (and later mobile) technologies and communications, the media have undergone significant transformation. New achievements not only affected traditional media in the classical sense, but also led to the emergence of new media. Based on new, digital media, directly related to the evolution of computers and the Internet, and widely implemented in various spheres, they have become more interactive than traditional media, which also significantly differed from them. However, at the beginning of the emergence of new media, this term was often understood as the actual process of emergence and development of digital and network technologies and communications ${ }^{36}$. As A. Lyakhov put it, "technologies are the environment where media live $<\ldots>$ new media are the ones that live in the wrong place where traditional media exist ${ }^{37}$. So, new media is media based on new technologies. At first glance, everything seems obvious. However, the question of what technologies to refer to the new ones further arises. The Canadian Broadcasting and Telecommunications Commission proposes the following definition: "New media are media services that are distributed over the Internet and include a wide range of communication products and services using video, audio, graphics and alphanumeric text. Such services include, but are not limited to, video games, email, online paging, fax, e-commerce and IP telephony" ${ }^{38}$.

D. McQuale gives the following main characteristics of new media: they are computer-based; they are flexible, hybrid; they have

${ }^{35}$ Рогалева О. С. Новые Медиа: эволюция понятия (аналитический обзор) / О. С. Рогалева, Т. В. Шкайдерова. - Вестн. Омского ун- та, 2015. - № 1. C. 222-225.

${ }^{36}$ Нові медіа в сучасному суспільстві: культурологічний вимір: монографія / В. М. Судакова, М. Ю. Наумова та ін. - К.: Інститут культурології НАМ України, 2017. - 352 с., С. 50.

37 Ляхов О. Доповідь на круглому столі, проведеному 22 листоп. 2012 р. в Києві за ініціативи Громадської Ради при Національній Раді України з питань телебачення та радіомовлення [Електронний ресурс] / О. Ляхов. Режим доступу: http:///www.nrada.dov.ua/2012/22/19.

${ }^{38}$ Проценко Д. Тупчієнко «Огляд підходів до регулювання нових конвергентних аудіовізуальних засобів масової інформації: міжнародний досвід», К. 2012, 112 с. 
interactive potential; they perform both private and public functions; they are characterized by a low degree of regulation; they are internally integrated, non-localized and omnipresent; they have access to other communications; they are an environment for both mass and individual communication $^{39}$.

However, does this imply a gradual withdrawal of traditional media, their destruction by new media? - asks a question in her article ${ }^{40}$. "The answer is definitely no. In fact, there is not a single "deadly" confrontation between traditional and new media, only competition, struggle, rather than even a search for the consumer. The technogenic civilization of the information society implies a new strategy of interrelation between media, information and the Internet. It consists in their mutual influence, which is expressed in the interinetration of media and medialization of the World Wide Web.

Among a large number of definitions of new media, there is an example of their interpretation presented in the WEBopedia dictionary: "New Media" - "a common term for many different forms of electronic communication based on computer technology. Term separates the notion of old (traditional) media, such as printed newspapers and magazines, which represented texts, graphics and photos. New media include: websites; audio and video streaming; all kinds of interactive chats; e-mail; on-line communication; electronic advertising; dvd and cd-rom media; electronic virtual games; integrated databases for the phone, such as Internet telephony; digital broadcasting; mobile communications, etc" ${ }^{41}$. However, although such a definition is generally accepted, technological evolution will obviously still make appropriate adjustments.

So, "new media" is a phenomenon of the modern information space. The content of new media means new forms of communication between content creators and consumers, which is especially evident in "social media" as one of the types of new media.

Social media has since its inception been identified solely with the blogosphere, but today it includes, in addition to blogs, social networks,

39 [McQuail D. Mass Communication Theory / D. McQuail; 6th edition. London: SAGE, 2010. - 632 p., P.41.

40 Нові медіа в сучасному суспільстві: культурологічний вимір: монографія / В. М. Судакова, М. Ю. Наумова та ін. - К.: Інститут культурології НАМ України, 2017. - 352 с., С. 50.

41 Webopedia / new media [Електронний ресурс]. - Режим доступу : http://www.webopedia.com/TERM/N/new_media.html. 
Internet forums, Wikipedia projects, podcasts and videos. There are many definitions of social media. Some identify with social networks, as in the Oxford Dictionary, which defines social media as websites and applications used for social networking. "The Social Media Guide website" has identified around 50 definitions of social media. Andreas Kaplan and Michael Henline define social media as: "Social media is a group of Internet applications that build on the ideological and technological principles of the second web and allow users to create and share content ${ }^{42}$. The possibilities of social media allow users to interact with each other and with society, to create communities.

Social media are distributed to blogs, social networks, data exchange services, social databases, social question and answer sites, referral, social sites.

Social media are understood as online communication in which the individual changes his or her role smoothly and flexibly, acting both as an audience and as a participant. Thus, interactivity and the large amount of content created by users is the main feature of social media. All these characteristics distinguish them among new media and make them social.

\section{CONCLUSIONS}

Modern media actively influence the state of culture. The media world of culture is filled with new meanings, images and signs. The values of the modern man are being reformatted. In modern scientific research, the research of transformation processes caused by technological innovations is becoming more and more relevant, including the scientific understanding of the phenomenon of media culture, the potential and prospects for the impact of new media on all spheres of life.

The study of the formation of media culture as a direction of scientific research, allows us to conclude that media culture is a type of culture of the newest era.

Thus, research into the formation of media culture as a direction of scientific research leads to the conclusion that media culture is a type of culture of the newest era. It should be understood as a set of material and intellectual values in the field of media.

42 Social Media and its Origins [Електронний ресурс] - Режим доступу до ресурсу: http://www.defence.gov.au/pathwaytochange/Docs/SocialMedia/ 1.\%20Social\%20media\%20and\%2 0its\%20origins\%20SM.pdf. 
The scientific views analyzed in this article demonstrate a variety of interpretations and vectors of research of such a complex and multifaceted phenomenon as mediaculture.

In modern times, there is a growing interest in the theoretical basis and practical formation of mediaculture. In research approaches mediaculture is considered as a form of communication relations, a powerful factor of acceleration of historical development, in which the media environment is a way of civilization development, as a factor of anthropological shifts, etc.

We believe that these terms cannot be considered equivalent to the notion of "media culture", as they reflect only one aspect of the existence of this complex phenomenon. Therefore, the article clarified the interpretations of these concepts and established a correlation to the notion of "mediaculture".

\section{SUMMARY}

The article deals with formation of mediaculture as direction of scientific research. Mediaculture becomes a manifestation of culture itself and is interpreted as universal access to culture for people through mass media products. Cultural interpretations of concepts related to modern mediaculture - "mass media", "media space", "new media", "social media", etc.

The article attempts to make a culturological interpretation of the basic concepts of mediaculture - media space, mass media, new media, social media. The definition of the main characteristics of the notions "media space", "mass media", "new media" and "social media" allows concluding that despite the interrelationship and general conceptual orientation, these notions have certain semantic differences. Namely, the media space in the broad sense acts as an asset of culture, an environment of information functioning, which with the development of technologies becomes a global media space. The media are understood as media that function in the media space. "New Media" - a term that began to be actively used with the advent of new interactive electronic publications, new forms of communication for content producers. New media are considered as a set of digital, network, communication technologies in the media industry. New media are a type of communication "from many to many", as opposed to media where communication is "from one to many". New media as a phenomenon of the modern information space, combine phenomena and processes that are different in nature and are changing dynamically. Their form is social media, characterized by interactivity and 
a large amount of content created by users. Social media as new channels of communication are gradually becoming the main drivers of change. Social media, more than traditional, focuses on discussion and the creation of new values. This is their natural property.

New media are transforming mediacultures, influencing not only traditional media, but the entire spectrum of social communications, changing their form and content and affecting daily life.

\section{REFERENCES}

1. Алферова 3. И., Алферов А. Н., Національне та європейське в сучасній українській медіаосвіті // Культура України. Сер. Мистецтвознавство : зб. наук. пр. / Харків. держ. акад. культури ; за заг. ред. В. М. Шейка. - Харків: ХДАК, 2016. - Вип. 53. - 372 с.

2. Appadurai A. Disjuncture and Difference in the Global Cultural Economy [Electronic resource] / Arjun Appadurai // Theory Culture Society. - 1990. - Vol. 7. - P. 295-310.

3. Бодріяр Ж. Симулякри і симуляція / Жан Бордіяр. - К.: «Основи», 2004. - $230 \mathrm{c.}$

4. Бурдье П. Социология политики / Пьер Бурдье // Социология политики; [пер. с фр. Н.А. Шматко]. - M.: Socio-Logos, 1993. -336 с.

5. Верховская С. Б. Медиакультура как фактор трансформации сознания // Вестник угроведения № 2 (5), 2011. Философия, сочиология, политология, С. 93-99.

6. Возчиков В. А. Философия образования и медиакультура информационного общества: дис. ... д-ра филос. : 09.00.11 / Вячеслав Анатольевич Возчиков. - Санкт Петербург, 2007. - 413 с.

7. Дебор Г. Общество спектакля / Ги Дебор; [пер. с фр. С. Офертаса и М. Якубович]. - М.: Логос, 1999. - 224 с.

8. Етимологічний словник української мови: В 7 т. - Т. 6: У-Я / Ред. кол.: О. С. Мельничук (гол. ред.), В. Т. Коломієць, Т. Б. Лукінова, Г. П. Півторак, В. Г. Скляренко, О. Б. Ткаченко; Укладачі: Г. П. Півторак, О. Д. Пономарів, І. А. Стоянов, О. Б. Ткаченко, А. М. Шамота. НАН України. Ін-т мовознавства ім. О. О. Потебні. К.: Наукова думка, 2012. - 568 с.

9. Землянова Л. М. Коммуникативистика и средства информации. Англо-русский толковый словарь концепций и терминов. Москва, 2004. $416 \mathrm{c}$.

10.Зубанова Л. Б. Современное медиапространство: подходы к пониманию и принципы интерпретации [Электронный ресурс] / Л. Б. Зубанова // Вестник Челябинской государственной академии 
культуры и искусств. - 2008. - № 2 (14). - С. 6-17. - Режим доступу : http://elibrary.ru/contents.asp?issueid=521114.

11.Кастельс М. Информационная эпоха: экономика, общество и культура / Мануэль Кастельс; [пер. с англ. под науч. ред. О. И. Шкаратана]. - М.: ГУ ВШЭ, 2000. - 608 с.

12. Kellner D. Media Culture: Cultural studies, identity and politics between the modern and postmodern / D. Kellner. - London ; New York, 2000. - 357 p.

13.Кириллова Н. Б. Что такое медиакультура // ТелеЦЕНТР. 2005. № 4 (12). С. 19-21.

14.Кириллова Н. Б. Многообразие культур в глобальном медиапространстве [Электронный ресурс] / Н. Б. Кириллова // Известия Уральского государственного университета. Сер. 2, Гуманитарные науки. - 2006. - № 47, Вып. 12. - С. 58-68. - Режим доступа : http:// hdl.handle.net/10995/23304.

15. Кулибаба С. И. Медиапространство и трансляция духовных ценностей [Электронный ресурс] / Сергей Иванович Кулибаба // Материалы Международ. науч. конф «Медиакультура новой России: методология, технологии, практики» / [под ред. Н. Б. Кирилловой и др.]. - 2007. - Т.2 - С. 125-134. - Режим доступа: http://vk.com/ doc-54830594_213541276.

16.Лассуєлл Г. Д. Психопатология и політика [Ел. рес.] / Г. Д. Лассуєлл. - Режим доступу: http://sbiblio.com/biblio/archive/ lasuel_psi

17. Липпман У. Общественное мнение / Уолтер Липпман; пер. с англ. Т. В. Барчунова, под ред. К. А. Левинсон, К. В. Петренко. М.: Институт Фонда «Общественное мнение», 2004. - 384 с.

18. Литвинович М. Как интернет меняет медиапространство. Интеллектуальная Россия. [Электронный ресурс] / Марина Литвинович // Интерлос. - Режим доступа: www.intelros.ru/intelros/reiting/ reyting_09/material_sofiy/8763-kak-internetmenyaetmediaprostranstvo. html.

19. Ляхов О. Доповідь на круглому столі, проведеному 22 листоп. 2012 р. в Києві за ініціативи Громадської Ради при Національній Раді України з питань телебачення та радіомовлення [Електронний pecypc] / О. Ляхов. Режим доступу : http:///www.nrada.dov.ua

20.Маклюэн Г. М. Понимание Медиа: Внешние расширения человека / пер. с англ. В. Николаева; закл. ст. М. Вавилова. М.-Жуковский: «КАНОН-пресс-Ц.», «Кучково поле», 2003. 464 с. 
21.Маклюэн М. Понимание медиа: внешние расширения человека [Электронный ресурс] / Маршалл Маклюэн; [пер. с англ. В. Николаева]. - М.: Канон-Пресс, 2003. - 458 с.

22. McLuhan M., Fiore Q. War and Peace in the Global Village. N.Y.: Bantam, 1968.

23. McQuail D. Mass Communication Theory / D. McQuail ; 6th edition. - London : SAGE, 2010. - 632 p.

24.Наумова М. Ю. Нові медіа та традиційні 3МІ: моделі співіснування / М. Ю. Наумова // Актуальні проблеми соиіології, психології, педагогіки. - 2011. - Вип. 13. - С. 86-92. - Режим доступу: http://nbuv.gov.ua/UJRN/apspp.

25.Пискун Т. В. Медиапространство как особая социальная структура: к методологии вопроса [Электронный ресурс] / T. В. Пискун // Режим доступа: www.readera.org/article/ medyeaprostranstvo-kak-osobaja-sotsyealnaja-0-10118474.

26. Проценко Д., Тупчієнко Д. «Огляд підходів до регулювання нових конвергентних аудіовізуальних засобів масової інформації: міжнародний досвід», К. 2012, 112 с.

27.Рашкофф Д. Медиавирус. Как поп-культура тайно воздействует на ваше сознание [Электронный ресурс] // Библиотека Гумер - гуманитарные науки. URL: http://www.gumer.info/ bibliotek_Buks/Gurn/Rashk.

28. Рогалева О. С. Новые Медиа: эволюция понятия (аналитический обзор) / О. С. Рогалева, Т. В. Шкайдерова. - Вестн. Омского ун-та, 2015. - № 1. - С. 222-225.

29. Судакова В. М С.24 Нові медіа в сучасному суспільстві: культурологічний вимір: монографія / Судакова В. М., М. Ю. Наумова та ін. - К.: Інститут культурології НАМ України, 2017. - 352 с.

30. Social Media and its Origins [Електронний ресурс] - Режим доступу до pecypcy: http://www.defence.gov.au/pathwaytochange/ Docs/SocialMedia/1.\%20Social\%20media\%20and\%20its\%20origins\% 20SM.pdf.

31. Waters M. Globalization / Malcolm Waters. - L.: Routledge. 1996. -185 p.

32. Webopedia / new media [Електронний ресурс]. - Режим доступу : http://www.webopedia.com/TERM/N/new_media.html.

33. Хоркхаймер М., Адорно Т. В. Диалектика просвещения. Филофоские фрагмен- ты / Макс Хоркхаймер, Теодор В. Адорно; [пер. с нем. М. Кузнецова]. - М.-СПб.: Медиум, Ювента, 1997. - 312 с. 
34. Черемушкина Е. Ф. Основоположник британських «культурных исследований» Ричард Хогарт. [Електронний ресурс] / Е. Ф. Черемушкина. - Режим доступу: http://study-english.info.

\section{Information about the author:}

\section{Uvarova T. I.,}

PhD in Arts, Associate Professor at the Department of arts and humanities studies, International Humanitarian University, 33, Fontanska Road St., Odessa, 65009, Ukraine 